\title{
Tratamento biológico de efluentes: fundamentos e aplicações
}

Geraldo Lippel Sant'Anna Jr.

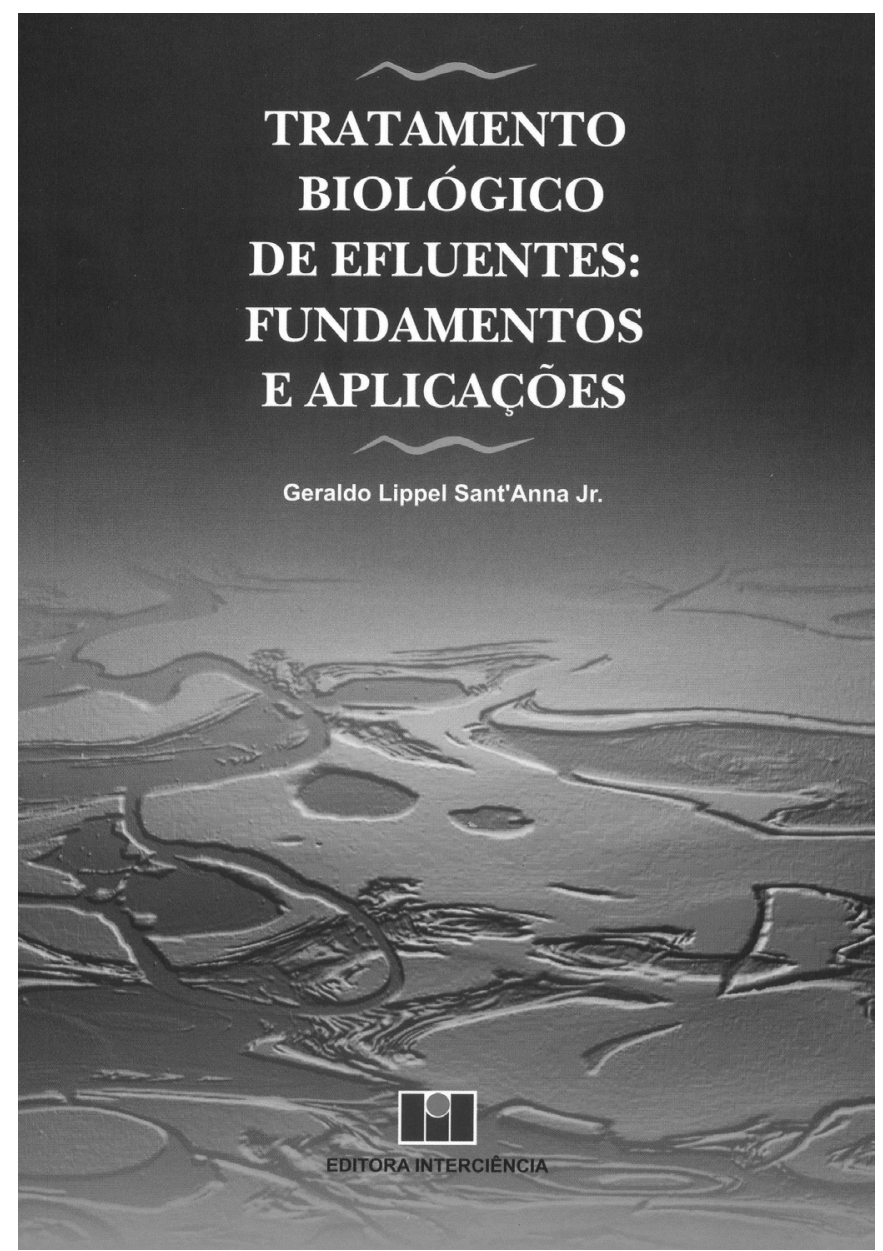

O livro do Professor Geraldo Lippel de Sant'Anna Jr., da COPPE/ UFRJ, lançado em fins de 2010 pela Editora Interciência, é efetivamente uma joia, cobrindo os fundamentos e aplicações do tratamento biológico. Muito completo, com quase 400 páginas, cobre bem os aspectos relativos aos agentes microbianos responsáveis pela degradação biológica, as principais vias metabólicas, os parâmetros de processo e os processos biológicos em si.

Riquíssimo em referências bibliográficas, tem, ao final de cada capítulo, sugestões de leitura complementar, nos quais não só livros recomendados como leitura complementar são indicados, mas também os capítulos de interesse em cada uma das referências recomendadas, o que é raro em nossas publicações. Vale lembrar ainda que a extensa relação de referências bibliográficas abrange tanto livros como artigos técnicos em revistas indexadas, de nosso país e do exterior.

Os aspectos que o autor coloca como "fundamentos" são claramente complementados pelo que chama de "aplicações". Há vários exercícios resolvidos no texto e, ao fim dos capítulos, questões práticas para resolver, o que torna esta obra extremamente interessante a estudantes de graduação e pós, particularmente engenheiros químicos e sanitaristas, além de biólogos.

Os três primeiros capítulos dedicam-se aos fundamentos biológicos, à conceituação da biodegradação e à poluição das águas. Os demais abordam de modo claro e objetivo os processos biológicos de tratamento, aeróbios e anaeróbios. Importante observar, os dois penúltimos capítulos dedicam-se à remoção do nitrogênio e do fósforo e o último apresenta tendências e expectativas com processos recentes, consolidados e novos.

Capítulo 1 - Comunidades microbianas e tratamento biológico;

Capítulo 2 - Biodegradação de poluentes orgânicos;

Capítulo 3 - Poluição hídrica - parâmetros e indicadores de interesse;

Capítulo 4 - Processos aeróbios para remoção da matéria orgânica tipos e variantes;

Capítulo 5 - Processos aeróbios para remoção da matéria orgânica aspectos cinéticos e de projeto;

Capítulo 6 - Transferência de oxigênio;

Capítulo 7 - Processos anaeróbios para remoção da matéria orgânica;

Capítulo 8 - Remoção biológica de nitrogênio;

Capítulo 9 - Remoção biológica de fósforo;

Capítulo 10 - Desafios e tendências do tratamento biológico de efluentes.

O livro do Professor Geraldo Lippel é, certamente, um dos três melhores escritos no país sobre o tema. À venda na Livraria Virtual da ABES.

\section{Comentário elaborado por Eduardo Pacheco Jordão, Coordenador da Coluna Livros: Luiz Fernando Cybis}

A sessão "Livros", que a cada edição traz resumos comentados sobre livros de interesse na área, tem como principal objetivo permitir que o leitor, de forma rápida, se atualize e conheça o que há disponível no mercado editorial. As contribuições deverão ser encaminhadas para: resa@abes-dn.org.br 